\title{
Producción y usos de Tenebrio molitor
}

\author{
Production and uses of Tenebrio molitor \\ Iliana A. Herrera-Soto ${ }^{a}$, Sergio Soto-Simental ${ }^{a}$, Juan Ocampo-López ${ }^{a}$, Maricela Ayala- \\ Martínez ${ }^{a}$ Armando Zepeda-Bastida ${ }^{a^{*}}$
}

\begin{abstract}
:
The aim of work is to propose the insect Tenebrio molitor as a nutritional alternative and report on their production methods, because not only have nutritional characteristics needed for a good diet for its nutritional high, but also have a variety of qualities beneficial to the health of consumers. It is well known that Mexico is a country with nutritional problems, due to lack of knowledge about nutritional deficiencies and options that people have in their diet; so that an alternative to this problem is to expand knowledge and food choices. Tenebrio molitor is known as a nutritional option for the large number of proteins containing, which provide a nutritional option, in addition to the health benefits that may be due to the presence of bioactive peptides. Not much is known about the management that these insects must have to avoid pests or infections during their production, in addition to the specific care necessary for rapid and sustainable production.
\end{abstract}

\section{Keywords:}

Insect consumption, nutritional alternative, protein, coleopter

\section{Resumen:}

El objetivo del trabajo es proponer el insecto Tenebrio molitor como alternativa nutricional e informar sobre los métodos de producción de este, ya que no solo tienen las características nutricionales necesarias para una buena dieta por su alto contenido nutricional, sino que también tienen una variedad de cualidades benéficas para la salud de los consumidores. Es bien sabido que México es un país con problemas nutricionales, debido principalmente a la falta de conocimientos sobre opciones nutricionales y a las deficiencias que las personas tienen en su dieta; por lo que una alternativa a esta problemática es ampliar el conocimiento y opciones alimenticias. El Tenebrio molitor es conocido como una opción nutricional por la gran cantidad de proteínas que contiene, lo que proporcionan una opción nutricional, además de los beneficios para la salud que pueden tener gracias a la presencia de péptidos bioactivos. No se sabe mucho sobre el manejo que estos insectos deben tener para evitar plagas o infecciones durante su producción, además de los cuidados específicos necesarios para una producción rápida y sostenible.

\section{Palabras Clave:}

Consumo de insectos, alternativas nutricionales, proteína, coleóptero

\section{Introduction}

Insects are part of the diet in some regions, they are used as a source of protein. Human consumption of insect is associated with countries located in Asia, Latin America and Africa due to its high consumption reported in these places [6]. In tropical countries, most insects are collected from nature, in an inventory carried out, more than 2000 species of edible insects were recognized worldwide;

a Universidad Autónoma del Estado de Hidalgo, Instituto de Ciencias Agropecuarias. Ave. Universidad s/n. ExHacienda de Aquetzalpa, Tulancingo, Hidalgo. MÉXICO. Iliana A. Herrera-Soto, aleli_herrera@ hotmail.com; https://orcid.org/0000-0002-6923-0928 Sergio Soto Simental, sotos@uaeh.edu.mx, https://orcid.org/0000-0002-6923-0926; Juan Ocampo López, jocampo@uaeh.edu.mx, https://orcid.org/0000-0002-9208-7216; Maricela Ayala Martínez, ayalam@uaeh.edu.mx, https://orcid.org/0000-0001-5554-218X;; Armando Zepeda Bastida, azepeda @ uaeh.edu.mx, https://orcid.org/0000-0003-0572-5206.

*Autor de Correspondencia, Universidad Autónoma del Estado de Hidalgo, https://orcid.org/0000-0003-0572-5206, Email: azepeda@uaeh.edu.mx. 
however, many edible insects have not yet been identified [11]. Insects can be consumed in their different stages: larva, pupa and adults and are used for human food since prehistory. The percentage of insects consumed in order is: coleoptera $(31 \%)$, lepidoptera $(18 \%)$, hymenoptera $(14 \%)$, orthoptera $(13 \%)$ and hemiptera $(10 \%) 23$. They are able to provide the recommended daily amounts of minerals, among which we can mention $\mathrm{Fe}, \mathrm{Ca}, \mathrm{Cu}, \mathrm{Mg}$, $\mathrm{Mn}$ and $\mathrm{Zn}$ the amount depends on the form of consumption and the number of insects in the diet [8]. It is difficult to generalize about his nutritional composition, but it is known that most insects provide a lot of energy, protein and amino acids necessary for humans, are rich in monounsaturated fatty acids and polyunsaturated fatty acids, contain vitamins and minerals. They have high concentrations of iron and zinc, higher than those of conventional meat (Table 1) [24].

Table 1.- Nutritional content of different insects.

\begin{tabular}{lccccc}
\hline \multicolumn{1}{c}{ Insect } & $\begin{array}{c}\text { Protein } \\
(\mathbf{g} / 100 \mathbf{~ g})\end{array}$ & $\begin{array}{c}\text { Fat } \\
(\mathbf{g} / \mathbf{1 0 0} \mathbf{~ g})\end{array}$ & $\begin{array}{c}\text { Minerals } \\
(\mathbf{g} / 100 \mathbf{~ g})\end{array}$ & $\begin{array}{c}\text { Carbohydrates } \\
(\mathbf{g} / 100 \mathbf{~ g})\end{array}$ & $\begin{array}{c}\text { Energy } \\
(\mathbf{k c a l} / 100 \mathbf{~ g})\end{array}$ \\
\hline Beetles & $3.7-54$ & $3.7-52$ & $1-3$ & $12-34$ & $126-574$ \\
Flies & $17.5-67$ & $4.2-31$ & $1.24-8$ & $8.38-23$ & $199-460$ \\
Grasshopper & $33-65$ & $7-54$ & $1-19$ & $7-19$ & $329-622$ \\
Bees & $1-81$ & $1.3-62$ & $0-6$ & $5-94$ & $234-593$ \\
Butterflies & $13.2-69.6$ & $7-77$ & $2-8$ & $3-41$ & $126-762$ \\
Crickets & $13-77$ & $2.4-25.14$ & $2-27$ & $16-30$ & $117-436$ \\
\hline
\end{tabular}

\section{Tenebrio molitor}

The coleoptera order is the richest order of insects in species, having around 300,000 already registered, it is also the most variable in size, and there are specimens of $0.25 \mathrm{~mm}$ up to $15 \mathrm{~cm}$ in length. Many of its species are pests of cultivated plants, fruit trees and forests [14]. The Tenebrionidae family is the richestin species, dispersed in warm and arid areas of the planet; larvae and adults feed on plant debris or derivatives, some species of the genera Tribolium, Gnathocerus, Palorus and Tenebrio generally live in the soil and take refuge under stones [4]. Tenebrio molitoris an edible insect that measu res approximately 2.5 to $3 \mathrm{~cm}$, it is consumed in many countries such as Africa, Asia and Australia, is an insect known as a yellow worm and black weevil, it is considered a secondary pest because it's the feeding of grains and seeds [8].

Tenebrio molitor has characteristics that different it from other insects and make it ideal for production and reproduction, among which we can mention to be resistant to certain types of radiation (Co gamma rays at rates of 30 kiloroentgens) ranging from exposures of 8,32 and $64 \mathrm{Kr}$, unlike other insects such as house crickets [16], likewise resists low amounts of oxygen without affecting its life cycle, however if there may be developmental abnormalities or a slower development [15]; shows immunocompetence, referred to the ability of an individual's immune system to resist infections and control pathogens [19], several studies have been carried out on the immunity of Tenebrio molitor, in one of them is known to have an adaptive immunity, responds with a long-lasting against antimicrobial activity that provides protection against exposure to pathogens, such as fungi [16].

\section{Taxonomic classification of Tenebrio molitor}

Animalia Kingdom

Edge: Arthropoda

Class: Insect

Order: Coleoptera

Family: Tenebrionidae

Gender: Tenebrio

Species: molitor $L 7$.

\section{Life cycle of Tenebrio molitor}

The life cycle can be divided into four phases, this begins with the eggs, then passes to the larva, pupa or chrysalis and finally the adult female oviposit to begin the cycle again (Figure 1), females oviposit for the first time at 11.5 days of age [17].

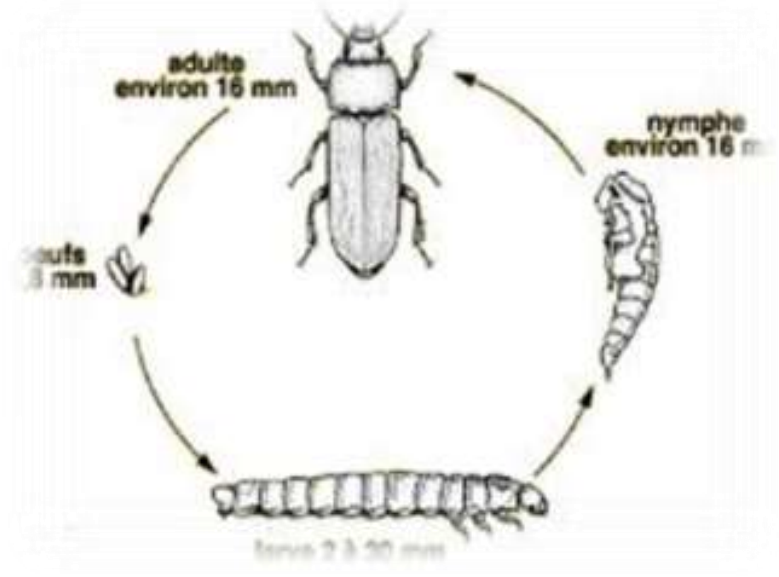

Figure 1.- Life cycle of Tenebrio molitor.

The life of the insect is approximately 280 days and this depends on the temperature, quality and accessibility of the food, larvae live for 3 to 4 months, the pupae for 3 to 4 weeks and pass to the adult stage in which they last for 2 to 3 months 1 , the nutritional value varies depending on the life stages as shown in Table 2, [21].

Table 2.- Nutritional value of Tenebrio molitor stages.

\begin{tabular}{lccc}
\hline \multirow{2}{*}{ Nutrient } & Larvae & Pupae & Adult \\
\cline { 2 - 4 } & & $\mathbf{( g / 1 0 0 ~} \mathbf{~ g )}$ & \\
\hline Carbohydrates & 5.4 & 3.69 & 4.9 \\
Fat & 37.2 & 42.48 & 46.2 \\
Fiber & 6.5 & 2.4 & 7.6 \\
Protein & 51.64 & 57.82 & 63.85 \\
Humidity & $62.42 \%$ & $64.35 \%$ & $63.84 \%$ \\
\hline
\end{tabular}

\section{Tenebrio molitor diet}

The basic requirements known for feeding Tenebrio molitorare sources rich in glucose, starch, salt, vitamin B 
and water [9], can gnaw the cardboard and wood in the packaging so they are considered a pest [12]; feeding them with wheat bran and lettuce is a viable option [15], the bran mustbed is aboutapproximately $3 \mathrm{~cm}$, this should be changed every third days, lettuce should be administered every two days taking care that the bed and the environment is not too wet since this can lead to the growth of undesirable fungi. An option in addition to lettuce is the tomato, but when providing them this must be very careful since it gives them an undesirable smell if leftmore than 36 hours in the box in addition to being more likely to leave fungi. Entomopathogenic fungi can infect insects through the penetration of their cuticles, through multiple mechanisms of action, which gives them a high capacity to prevent the host from developing resistance. The fungus Beauveria bassiana and Vuill (Hypocreales: cordycipitaceae), is one of the most studied species in the world, and can infectmore than 200 species in nine orders of insects [27], it is for this reason that the substrate and food that is offered to the insect must be observed closely, this prevents fungal contamination.

Tenebrios can be alojated in plastic boxes with the following measures $15 \mathrm{~cm}$ long, $14 \mathrm{~cm}$ wide and $9 \mathrm{~cm}$ high, in each box 100 to 150 tenebrios can be accommodated [15]; they can also be hou sed in tall plastic containers with bran (Figure 2), or with a different substrate such as com, soybeans and rice. Symbiotic microorganisms are known to have a significant effect on host metabolism and therefore affect larval growth, may help to increase food digestibility and bioconversion efficiency by stimulating metabolism, these can be found on the substrates offered [14].

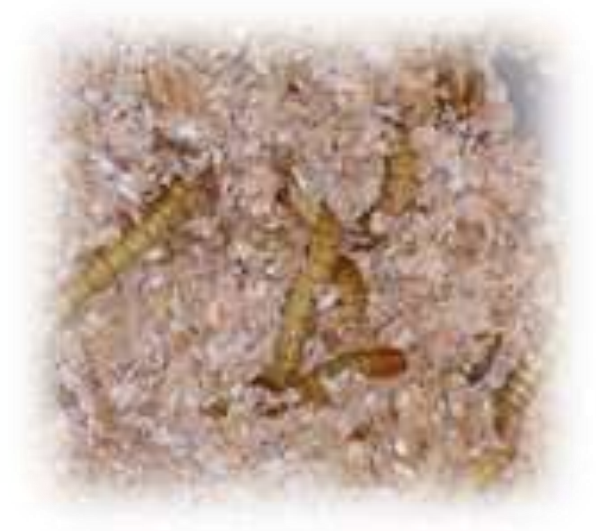

Figure 2.- Tenebrio molitor on wheat bran bed.

Temperature must be controlled, as it determines the number or number of offspring and also influences the determination of sex. The low temperatures let up their life cycle and also causes some tenebrios to perish during their different stages [2], having a larger quantity of larvae there is an increase in density after 1 month of development; however, female and adult pupae that are raised in isolation are significantly larger than those with densities greater than 20 larvae, normally female pupae are significantly larger than male pupae when raised in isolation [26].

\section{Uses of Tenebrio molitor}

Tenebrio molitor is considered a pest and for flour companies it is undesirable since it accounts for $50 \%$ of production losses; but in nutrition human and animal, the tenebrio considered an excellent sou rce of protein, the first stage is an egg, it is small and it is not customary to consume itdue to its size; the second stage is larva, which is consumed mostly, being one of the most commercialized in sects in Eu rope, it contributes up to $62 \%$ protein and is considered a perfect start to entomophagy due to its delicate flavor, they have a light hazelnut flavor and cooked they easily acquire the flavor of complementary foods, they are also sold fried or dehydrated, the crisp texture which is what is ideal for consumption in the form of a snack, they can also be added to smoothies as a source of protein. The third and fourth stages are pupa and adult, these are not normally consumed but they also represent a good sou rce of protein and essential amino acids [21]. Tenebrio molitor has been used in diets for broilers as a source of protein evaluating the effect on growth, digestibility of nutrients and carcass and meat traits. Chickens fed this diet obtained a higher feed conversion than those fed a diet with conventional protein source [5]. Its use is mainly made in its larval stage, mainly to serve as food for an imal species such as reptiles, birds and fish. Tenebrio molitor is one of the species most used for its breeding on insect farms, especially for live food [5], is one of the most widely used insects in insect farms due to its high protein content, which makes it possible to make feed for aquaculture that is rich from a nutritional point of view. Furthermore, it is expected that this species will be one of the most widely used for human consumption or entomophagy [27]. Proteins are responsible for the creation of tissues in living beings. Insects are important from a nutritional point of view because they are rich in proteins, both essential and nonessential (those that the body cannot generate). For this reason, through feeding from insects, we are providing the body with non-essential proteins [26].

Tenebrio molitor has also been used as a protein alternative in a diet to evaluate the performance of sea bream (Sparus auratasin). In this study it was shown that replacing fishmeal with Tenebrio molitor's flour does not cause any adverse effects in any parameter and gilthead can be marketed [18]. It has been shown that the Tenebrio molitor can be used as food for catfish fry, th is can su stain the growth of catfish fry giving a survival rate of $70 \%$ [22]. The Tenebrio molitoris an excellent source of protein also 


\section{used in diets for Rainbow Trout (Oncorhynchus mykiss) [10] obtaining encouraging results [13].}

References

[1] Allende M. Como criar Tenebrios (gusano de la harina) para alimento de gallina. Revista vía orgánica 2015; 3-6.

[2] Arana, E. (2018). Manejo en cautiverio de tenebrio molitor usando cinco tipos de harina. División de ciencias e ingenieria, 4-29.

[3] Barnes AI, Silva-Jothy MT. Density-dependent prophylaxis in the mealworm beetle Tenebrio molitor L. (Coleoptera: Tenebrionidae): cuticular melanization is an indicator of investment in immunity. Proc Biol Sci 2000; 267(1439): 177-182. DOI: 10.1098/rspb.2000.0984

[4] Barrientos JA. Curso práctico de entomología. Universidad Autónoma de Barcelona. Servei publicacions. España. 2004; 947 pág. ISBN $84-$ 490-2383-1.

[5] Bovera F, Loponte R, Marono S, Piccolo G, Parisi G, Laconisi V, Gasco L, Nizza A. Use of Tenebrio molitor larvae meal as protein source in broiler diet: Effect on growth performance, nutrient digestibility, and carcass and meat traits J Anim Sci 2016; 94(2): 639-647. https://doi.org/10.2527/jas.2015-9201

[6] Bukkens SGF. The nutritional value of edible insects, Ecol Food Nut 1997; 36(2-4): 287-319.DOI: 10.1080/03670244.1997.9991521

[7] Corona do PR, Márquez AD. Introducción a la entomología, morfología y taxonomía de los insectos. Agencia para el Desarrollo Internacional. Centro Regional de Ayuda Técnica. México, DF 1972; 282 pág.

[8] Feng S. Tenebrio molitor L., entomophagy and processing into ready to use therapeutic ingredients: a review. J Nutr Health Food Eng 2018; 8(3): 280-285. DOI: 10.15406/jnhfe.2018.08.00283

[9] Fraenkel G. The nutrition of the mealworm, Tenebrio molitor L. (Tenebrionidae, Coleoptera). Physiological Zoology 1950; 23(2): 92108.

[10] Gasco L, Belforti M, Rotolo L, Lussiana C, Parisi G, Terova G, Roncarati A, Gai F. Mealworm (Tenebrio molitor) as a potential ingredient in practical diets for rainbow trout (Oncorhynchus mykiss). Abstract book Conference "Insects to Feed The World" 2015; 14-17.

[11] Van Huis A. Edible insects contributing to food security? Agric \& Food Secur 2015; 4:20. DOI 10.1186/s40066-015-0041-5

[12] Intriago TSC, Valencia YB. Determinación de antocianinas y valor nutricional de los tenebrios (Tenebrio molitor) a limentados con dietas enriquecidas con maíz morado (Zea Mays L.). Universidad Politécnica Salesiana, Ecuador. Tesis de Licenciatura. 2014.77pág.

[13] Iaconisi, V., Marono, S., Parisi, G., Gasco, L., Genovese, L., Maricchiolo, G., \& Piccolo, G. (2017). Dietary inclusion of Tenebrio molitor larvae meal: Effects on growth performance and final quality treats of blackspot sea bream (Pagellus bogaraveo). Aquaculture, 476, 49-58. https://doi.org/10.1016/j.aquaculture.2017.04.007

[14] Leyuan, L., Beiz hen , X., Dong, C., Wang, M., \& Hong Liu. (2016). Can closed artificial ecosystem have an impact on insect microbial community? A case study of yellow mealworm (Tenebrio molitor L.). Ecological engineering, 183-189

[15] Loudon, C. (1988). Desarrollo de Tenebrio molitor en bajos niveles de oxígeno. Fisiología de insectos, 97-103.
[16] Menhinick, E., \& Crossley, D. (1968). Una comparación de los perfiles de radiación de Acheta domesticus y Tenebrio molitor. Reino Unido: Annals of the entomological society of a merica.

[17] Moreno DMG. Efecto de una bebida a base de Tenebrio molitor sobre la hepatocarcinogénesis experimental en el ratón. Universidad Autónoma delEstado de Hidalgo, México. Tesis de Maestría. 2018.

[18] Moret Y, Siva-Jothy MT. Adaptive innate immunity? Responsivemode prophylaxis in the mealworm beetle, Tenebrio molitor. Proc Biol Sci 2003; 270(1532): 2475-2480. DOI: 10.1098/rspb.2003.2511.

[19] Damborsky MP, Sandrigo-Ybran T, Bar ME, Oscherov E. Ciclo de Vida de Tenebrio molitor (Coleoptera, Tenebrionidae) en Condiciones Experimentales. UNNE 1999; 6: 52-68.

[20] Iaconisi, V., Secci, G., Sabatino, G., Piccolo, G., Gasco, L., Papini, A. M., \& Parisi, G. (2019). Effect of mealworm (Tenebrio molitor L.) larvae meal on amino acid composition of gilthead sea bream (Sparus aurata L.) and rainbow trout (Oncorhynchus mykiss W.) fillets. Aquaculture, $\quad 513, \quad 734403$. https://doi.org/10.1016/j.aquaculture.2019.734403

[21] Mendoza Calvo C. (2020). Insectos a la carta. Revisado 08/04/2020. Disponible en: https://insectosa lacarta.com/insectos-comestibles

[22] Rantala MJ, Kortet R, Kotiaho JS, Vainikka A, Suhonen J. Condition dependence of pheromones and immune function in the grain beetle Tenebrio molitor. Functional Ecology 2003; 17: 534-540. https://doi.org/10.1046/j.1365-2435.2003.00764.x

[23] Romer, F., Emmerich, H., \& Nowock, J. (1974). Biosynthesis of ecdysones in isolated prothoracic glands and oenocytes of Tenebrio molitor in vitro. Journal of insect physiology, 20(10), 1975-1987. https://doi.org/10.1016/0022-1910(74)90105-X

[24] Roncarati A, Gasco L, Parisi G, \& Terova G. Growth performance of common catfish (Ameiurus melas Raf.) fingerlings fed mealworm (Tenebrio molitor) diet. J Insect Food Feed 2015; 1(3): 233-240. https://doi.org/10.3920/JIFF2014.0006

[25] Soares de Castro RJ, Ohara A, Goncalves dos Santos JA, Fontenele MAD. Nutritional, functional and biological properties of insect proteins: Processes for obtaining, consumption and future challenges. Trends Food Sci Tech 2018; 76: 82-89. https://doi.org/10.1016/j.tifs.2018.04.006

[26] Weaver, D., \& McFarlane, J. (1990). El efecto de la densidad larvalen el crecimiento y desarrollo de Tenebrio molitor. Fisiología de insectos, 531-536.

[27] Zamora, J., Martínez, N., Guerrero, M., Fuentes-Guerra, J., \& Hernández, C. (2009). Control hormonal de la metamorfosis: hormona de la muda (o ecdisona), hormona juvenil. Open course ware Universidad de Sevilla, 7-8. 